\title{
MENINGKATKAN KUALITAS PENDIDIKAN MELALUI TEKNOLOGI INFORMASI
}

\author{
Husnul Fatarib \\ Program Studi Pendidikan Agama Islam Jurusan Tarbiyah STAIN Jurai Siwo \\ Korespondensi: Jln. Kihajar Dewantara No. 15A Metro Timur Lampung
}

\begin{abstract}
Information technology (IT) has become major facilitators for business practices, has yielded great contribution towards fundamental changes upon organizational structures, operations, and management. Automatic Telling Machine (ATM), ecommerce, online e-banking transfer, are the examples of the application of the technology and has made human's life even easier. The advancement of IT also contributes to educational system. Web-based learnings (e-learnings) are continuously developed by IT practitioners. Profiles of educational institutions, starting from basic level up to university ones, are easily accessed by society regardless where they live due to IT developments. Therefore, there should be great attempts made the government, especially Ministry of Education and Culture, to ensure that IT can reach all level of society and get rid of the possibility of quality gaps of education.
\end{abstract}

Kata kunci: kualitas pendidikan, teknologi, informasi

\section{PENDAHULUAN}

$\mathrm{R}$ evolusi informasi global merupakan suatu kemajuan teknologi yang menyatukan kemampuan komputerisasi, televisi, radio, telepon menjadi satu kesatuan. Hal ini merupakan hasil dari suatu kombinasi revolusi di bidang komputer pribadi, komunikasi data dan kompresi, bandwitdh, data strorage dan data access, integrasi multimedia dan jaringan komputer. Konvergensi dari revolusi teknologi tersebut telah menyatukan berbagai media, yaitu suara (voice, audio), video, citra (image), grafik, dan teks. Teknologi Informasi dapat menjadi alat pendorong ke arah kemajuan bangsa. Salah satu dampak terbesar adalah perkembangan pembangunan di bidang pendidikan. Hal yang merupakan jembatan menuju bangsa yang maju di mana masyarakat dapat memiliki alat-alat yang membantu mereka mengembangkan usaha dan menikmati hasilnya secara mudah, murah dan merata. Sesuatu yang merupakan kerangka akses untuk semua orang dalam mengarungi abad 21 ini.

Teknologi Informasi dapat membantu memberi perubahan besar di banyak negara. Dalam era global sekarang ini tidak ada lagi sekat dalam hal akses informasi sehingga semua lapisan masyarakat mempunyai kesempatan yang sama untuk mengembangkan diri dalam segala aspek kehidupan. Tentunya kita sebagai masyarakat Indonesia tidak dapat menolak terhadap "booming" Teknologi Informasi ini. Peranan dunia 
pendidikan menjadi pintu utama untuk menyaring, menstransfer dan memberikan constrainsts sehingga nilai-nilai tradisional yang positif tidak mudah terkikis bahkan kita berhadap dapat bergabung secara sinergi. Tentunya tugas kita semua untuk sama-sama berpikir mencari format terbaik bagaimana memanfaatkan dan mengevaluasi peranan Teknologi Informasi dalam meningkatkan kualitas pendidikan di tanah air tercinta ini.

Indonesia yang merupakan negara kepulauan, selalu menghadapi masalah dalam pembangunan pendidikan terutama dalam hal kesenjangan memperoleh layanan pendidikan yang optimal, sehingga terjadi perbedaan kualitas SDM yang mencolok sebagai akibat sulitnya akses bagi masyarakat yang belum tersentuh oleh akses informasi yang cepat. Dalam tulisan ini, penulis hanya sekedar menawarkan konsep bagaimana memanfaatkan kemajuan bidang teknologi informasi untuk meningkatkan kualitas pendidikan di Indonesia.

\section{SEJARAH PERKEMBANGAN TEK- NOLOGI INFORMASI}

Manusia adalah makhluk sosial, di samping sandang, pangan dan papan sebagai kebutuhan utamanya, maka sebagai makhluk sosial manusia membutuhkan untuk berkomunikasi diantara sesamanya sebagai kebutuhan utama untuk dapat saling berhubungan satu dengan yang lainnya. Manusia mencari dan menciptakan sistem dan alat untuk saling berhubungan tersebut, mulai dari melukis bentuk/menggambar di dinding gua, isyarat tangan, isyarat asap, isyarat bunyi, huruf, kata, kalimat, tulisan, surat, sampai dengan telepon dan internet. Alat dan sistem komunikasi yang diciptakan manusia tersebut kemudian dikenal dengan nama Teknologi Informasi atau yang lebih dikenal dengan istilah "IT" (dibaca ai-ti), singkatan dari Information Technology.

Perkembangan peradaban manusia diiringi dengan perkembangan cara penyampaian informasi (yang selanjutnya dikenal dengan istilah Teknologi Informasi). Mulai dari gambar-gambar yang tak bermakna di dinding-dinding gua, peletakkan tonggak sejarah dalam bentuk prasasti sampai diperkenalkannya dunia arus informasi yang kemudian dikenal dengan nama internet. Informasi yang disampaikan pun berkembang. Dari sekedar menggambarkan keadaan sampai taktik bertempur.

Pada awalnya Teknologi Informasi yang dikembangkan manusia berfungsi sebagai sistem untuk pengenalan bentukbentuk yang mereka kenal, mereka menggambarkan informasi yang mereka dapatkan pada dinding-dinding gua, tentang berburu dan binatang buruannya. Pada masa ini mereka mulai melakukan pengidentifikasian benda-benda yang ada di sekitar lingkungan mereka tinggal dan mewakilinya dengan bentuk-bentuk yang kemudian mereka lukis pada dinding gua tempat mereka tinggal, karena kemampuan mereka dalam berbahasa hanya berkisar pada bentuk suara dengusan dan isyarat tangan sebagai bentuk awal komunikasi mereka pada masa ini. Perkembangan selanjutnya adalah diciptakan dan digunakannya alat-alat yang menghasilkan bunyi dan isyarat, seperti gendang, terompet yang terbuat dari tanduk binatang, isyarat asap sebagai alat pemberi peringatan terhadap bahaya. Pada masa ini Teknologi Informasi belum menjadi teknologi masal seperti yang kita kenal sekarang, teknologi informasi masih digunakan oleh kalangan-kalangan terbatas saja, digunakan pada saat-saat khusus dan mahal.

3000 SM: Untuk pertama kali tulisan digunakan oleh bangsa Sumeria 
dengan menggunakan simbol-simbol yang dibentuk dari pictograf sebagai huruf. Simbol atau huruf-huruf ini juga mempunyai bentuk bunyi yang berbeda (penyebutan), sehingga mampu menjadi kata, kalimat dan bahasa.

2900 SM: Penggunakan Huruf Hierogliph pada bangsa Mesir Kuno, Hierogliph merupakan bahasa simbol di mana setiap ungkapan diwakili oleh simbol yang berbeda, yang ketika digabungkan menjadi satu akan mempunyai cara pengucapan dan arti yang berbeda, bentuk tulisan dan bahasa hierogliph ini lebih maju dibandingkan dengan tulisan bangsa Sumeria.

500 SM: Serat Papyrus digunakan sebagai kertas yang terbuat dari serat pohon Papyrus yang tumbuh di sekitar sungai Nil ini menjadi media menulis/media informasi yang lebih kuat dan fleksibel dibandingkan dengan lempengan tanah liat yang sebelumnya digunakan sebagai media informasi.

$105 \mathrm{M}$ : Bangsa Cina menemukan kertas. Kertas yang ditemukan oleh bangsa Cina pada masa ini adalah kertas yang kita kenal sekarang, kertas ini dibuat dari serat bambu yang dihaluskan, disaring, dicuci kemudian diratakan dan dikeringkan, penemuan ini juga memungkinkan sistem pencetakan yang dilakukan dengan menggunakan blok kayu yang ditoreh dan dilumuri oleh tinta atau yang kita kenal sekarang dengan sistem Cap.

Tahun 1455: Mesin cetak yang menggunakan plat huruf yang terbuat dari besi yang bisa diganti-ganti dalam bingkai yang terbuat dari kayu dikembangkan untuk yang pertama kalinya oleh Johann Gutenberg.

Tahun 1830: Augusta Lady Byron menulis program komputer yang pertama di dunia bekerjasama dengan Charles Babbage menggunakan mesin Analytical-nya, yang didesain mampu memasukkan data, mengolah data dan menghasilkan bentuk keluaran dalam sebuah kartu. Mesin ini dikenal sebagai bentuk komputer digital yang pertama walaupun cara kerjanya lebih bersifat mekanis daripada bersifat digital, 94 tahun sebelum komputer digital pertama ENIAC 1 dibentuk.

Tahun 1837: Samuel Morse mengembangkan Telegraph dan bahasa kode Morse bersama Sir William Cook dan Sir Charles Wheatstone yang dikirim secara elektronik antara 2 tempat yang berjauhan melalui kabel yang menghubungkan kedua tempat tersebut. Pengiriman dan penerimaan informasi ini mampu dikirim dan diterima pada saat yang hampir bersamaan waktunya. Penemuan ini memungkinkan informasi dapat diterima dan dipergunakan secara luas oleh masyarakat tanpa diiringi oleh jarak dan waktu.

Tahun 1861: Gambar bergerak yang diproyeksikan ke dalam sebuah layar pertama kali digunakan sebagai cikal bakal film sekarang.

Tahun 1877: Alexander Dewey mengembangkan sistem penulisan Desimal.

Tahun 1877: Alexander Graham Bell menciptakan dan mengembangkan telepon yang dipergunakan pertama kali secara umum. Fotografi dengan kecepatan tinggi ditemukan oleh Edward Maybridge.

Tahun 1899: Dipergunakan sistem penyimpanan dalam tape (pita) magnetis yang pertama.

Tahun 1923: Zvorkyn menciptakan tabung televisi yang pertama.

Tahun 1940: Dimulainya pengembangan ilmu pengetahun dalam bidang informasi pada masa perang dunia II yang dipergunakan untuk kepentingan pengiriman dan penerimaan dokumendokumen militer yang disimpan dalam bentuk magnectic tape. 
Tahun 1945: Vannervar Bush mengembangkan sistem pengkodean menggunakan Hypertext.

Tahun 1946: Komputer digital pertama di dunia ENIAC 1 dikembangkan.

Tahun 1948: Para peneliti di Bell Telephone mengembangkan transistor.

Tahun 1957: Jean Hoerni mengembangkan transistor Planar. Teknologi ini memungkinkan pengembangan jutaan bahkan milyaran transistor dimasukkan ke dalam sebuah keping kecil kristal silikon. USSR (Rusia pada saat itu) meluncurkan sputnik sebagai satelit bumi buatan yang pertama yang bertugas sebagai mata-mata. Sebagai balasannya Amerika membentuk Advance Research Projects Agency (ARPA) di bawah kewenangan Departemen Pertahanan Amerika untuk mengembangkan ilmu pengetahuan dan teknologi informasi dalam bidang militer.

Tahun 1962: Rand Paul Barand, dari perusahaan RAND, ditugaskan untuk mengembangkan suatu sistem jaringan desentralisasi yang mampu mengendalikan sistem pemboman dan peluncuran peluru kendali dalam perang nuklir.

Tahun 1969: Sistem jaringan yang pertama dibentuk dengan menghubungkan 4 nodes (titik), antara University of California, SRI (Stanford), University California of Santa Barbara, dan University of Utah dengan kekuatan 50 Kbps.

Tahun 1972: Ray Tomlinson menciptakan program e-mail yang pertama.

Tahun 1973-1990: Istilah INTERNET diperkenalkan dalam sebuah paper mengenai TCP/IP kemudian dilakukan pengembangan sebuah protokol jaringan yang kemudian dikenal dengan nama TCP/IP yang dikembangkan oleh grup dari DARPA, 1981 National Science Foundation mengembangkan Backbone yang disebut CSNET dengan kapasitas 56 Kbps untuk setiap institusi dalam pemerintahan. Kemudian pada tahun 1986 IETF mengembangkan sebuah server yang berfungsi sebagai alat koordinasi diantara: DARPA, ARPA-NET, DDN dan Internet Gateway.

Tahun 1991-sekarang: Sistem bisnis dalam bidang IT pertama kali terjadi ketika CERN dalam menanggulangi biaya operasionalnya memungut bayaran dari para anggotanya. 1992 pembentukan komunitas Internet dan diperkenalkannya istilah World Wide Web oleh CERN. 1993, NSF membentuk InterNIC untuk menyediakan jasa pelayanan internet menyangkut direktori dan penyimpanan data serta database (oleh AT\&T), Jasa Registrasi (oleh Network Solution Inc,) dan jasa informasi (oleh General Atomics/CERFnet), 1994 pertumbuhan internet melaju dengan sangat cepat dan mulai merambah ke dalam segala segi kehidupan manusia dan menjadi bagian yang tidak dapat dipisahkan dari manusia. 1995, Perusahaan umum mulai diperkenankan menjadi provider dengan membeli jaringan di Backbone, langkah ini memulai pengembangan Teknologi Informasi khususnya internet dan penelitian-penelitian untuk mengembangkan sistem dan alat yang lebih canggih.

\section{TEKNOLOGI INFORMASI}

Belum ada kesepakatan yang bisa diterima oleh berbagai kalangan berkenaan dengan konsep dan definisi teknologi informasi. Namun bilamana ditelusuri, teknologi informasi pada awalnya adalah dilandasi oleh teori-teori yang berkembang dalam ilmu komunikasi, di mana komunikasi adalah suatu proses di mana para partisipan menciptakan dan membagi informasi pada orang lain untuk mencapai saling pengertian (Rogers, 1986). Inti dari komunikasi 
adalah informasi adalah informasi, sedangkan alat yang digunakan dalam menyampaikan informasi adalah teknologi. Dengan demikian, maka teknologi informasi adalah suatu bentuk penyampaian informasi yang menggunakan kaidah-kaidah bersifat teknologis, baik dengan bantuan alat maupun program dari si pembawa pesan ke yang menjadi objek penerima pesan.

Perkembangan yang sangat cepat dalam teknologi informasi secara langsung berimbas pada sistem pendidikan kejuruan. Proses komputerisasi yang digunakan pada setiap level sistem pendidikan membuat teknologi informasi sebagai bagian integral dari sistem manajemen pendidikan di berbagai negara termasuk di Indonesia. Semisial dalam aktivitas hari ke hari dari sekolah berdampak kuat pada setiap aspek proses manajemen. Sekolah menghimpun data, komputer mengolah data dan memobilisasi data serta dapat mendukung para praktisi dalam aktivitas keseharian, memperbaiki efektivitas dan efisiensi serta membantu dalam pencapaian tujuan pendidikan.

Penggunaan teknologi informasi dapat membantu praktisi pendidikan dalam mempersiapkan diri untuk bekerja dengan lingkungan di dalam sekolah, antara sekolah maupun pada level daerah atau nasional secara berkelanjutan, aktual, tepat waktu dan reliabel. Selain itu penggunaan teknologi informasi ini dapat membantu dalam membuat dan mendistribusikan keputusan yang akan diambil dalam kerangka kepentingan dan tujuan kelembagaan.

Teknologi informasi secara potensial, mampu menyediakan bagi para praktisi sekolah pada setiap level sistem pendidikan dengan layanan informasi tentang apa saja yang tidak tercapai untuk mendesain dan mengimplementasikan upaya perbaikan dalam kualitas persekolahan, prestasi siswa dan kualitas tamatannya. Selain itu kontribusi yang diberikan oleh penggunaan teknologi informasi adalah pada perbaikan dan penyempurnaan sistem pendidikan, meningkatkan profesionalisme praktisi pendidikan dan menguatkan kepemimpinan sekolah.

Dalam terminologi teknologi informasi, terdapat tiga komponen utama yang melingkupinya, yakni: (1) management information system, atau sistem informasi manajemen, (2) hardware (perangkat keras), dan (3) faktor manusia. Sistem informasi manajemen (SIM) didefinisikan sebagai keterpaduan antara pengguna (user) dan sistem masinal dalam penyediaan informasi untuk mendukung pelaksanaan, manajemen dan fungsi pembuatan keputusan dalam sebuah organisasi.

Sistem Informasi Manajemen menurut Windham (1996: 308) adalah seperangkat struktur dan prosedur kerja meliputi pengumpulan, pemrosesan, analisis, presentasi dan penggunaan informasi dalam sebuah organisasi. Sedangkan dimensi dari SIM itu sendiri adalah teknologi, konteks manajemen, kerangka kerja konseptual struktur informasi dan bentuk susunan data yang digunakan. Penjelasan lain yang dikembangkan leh Windham (1996: 309), bahwa sebuah SIM akan mencapai keberhasilan bilamana dalam pengoperasiannya meliputi lima tahap, yakni: identifikasi kebutuhan, pengumpulan data, prosesing dan analisis data, provinsi informasi dan utilisasi informasi.

SIM dalam pendidikan kejuruan adalah suatu desain untuk me-link \& match-kan struktur pendidikan dengan perkembangan di dunia industri, tugastugas manajerial, proses pengajaran dan kebutuhan spesifik dari sistem pendidikan kejuruan itu sendiri. Sebagai suatu sistem yang dinamis dalam prosesing data dalam bentuk data base yang terpadu dan transformasi ke dalam produk 
atau output, perlu menggunakan modelmodel alternatif keputusan pada setiap perencanaan strategik, kontrol manajemen, kontrol pelaksanaan pada setiap level. Teknologi informasi ini juga didasarkan pada penggunaan perangkat komputer yang mampu menyediakan dukungan dalam pengambilan keputusan yang berkenaan dengan sistem pendidikan sebagai bagian yang teratur dalam manajemen organisasi.

Database yang integral dari SIM pendidikan kejuruan, meliputi data pada iterminologi: siswa, guru, praktisi pendidikan, kelas, level/tingkatan, bahasan, prestasi siswa dan perilakunya, konseling, bimbingan dan kesehatan, transportasi dan aktivitas ekstrakurikuler lainnya. Selain itu adalah database yang berhubungan dengan industri-industri yang terlibat sebagai institusi pasangan maupun industri yang menjadi stakeholder atau user bagi tamatan sekolah kejuruan, mengenai kebutuhan (supply and demand) dan kualifikasi tenaga kerja yang dibutuhkan.

SIM menyediakan pada para administratur pendidikan suatu bentuk dukungan dalam pembuatan keputusan, fungsi perencanaan dan pengawasan. SIM menurut Telem (1996: 591) adalah sebagai analisis yang sangat kompleks dan pembuatan profil proses pendidikan dan outcome-nya dan juga membantu dalam aktivitas lainnya. Sebagai contoh pada level sekolah kejuruan, semua praktisi, termasuk administratur sekolah, guru, dan instruktur seharusnya menerima dukungan dalam perbaikan pembuatan keputusan pada bermacam permasalahan sebagaimana dalam penugasan dan penyebaran sumberdaya, yakni dalam: keputusan staffing, adminission, penjadwalan, catatan perkembangan siswa dan perencanaan anggaran pendidikan dan akutabilitasnya.
Pada level daerah dan nasional, SIM dapat diarahkan untuk membantu dalam menentukan target dan standar kompetensi secara jelas, baik standar lokal maupun nasional yang reliabel untuk memperbaiki proses pembelajaran dan pengajaran dan pengalokasian waktu pembelajaran dan performan dari fungsifungsi komponen pendidikan (seperti keuangan sekolah, perpustakaan, kelas, penjadwalan sarana dan prasarana lainnya, penempatan personil dan lain-lain), perangkat software yang dikembangkan dan digunakan. Keseluruhannya dioperasikan sebagai bagian yang integral dari SIM pendidikan kejuruan pada level sekolah, daerah maupun level nasional.

Implementasi teknologi informasi, wujudnya adalah dengan menggunakan sistem komputerisasi sebagai alat sebagaimana penggunaan word-prosessing, electronik mail, arsip elektronik, automatic dialing, electric appointment books, dekstop publishing, spreadsheets atau lembar kerja dan sebagainya. Namun perlu diperhatikan adalah sistem dan teknologi informasi ini senantiasa mengalami perubahan yang sangat cepat, ini bisa dilihat dalam deskripsi tentang referensi kerja di dunia industri secara cepat berubah menjadi out-of-date atau sudah ketinggalan (Brandhorst, 1996: 330), sehingga penggunaan software dan hardware komputer pun dalam operasional sistem informasi manajemen ini senantiasa mengalami perubahan.

Setiap level sistem pendidikan seharusnya mempunyai sistem informasi manajemen pendidikan dan database yang terpadu, yang mampu melayani secara komprehensif dan menyeluruh. Kolaborasi atau kerjasama antara semua praktisi pendidikan pada setiap level dan di antara sekolah, antarsekolah, supervisi, penentuan formasi baru, pembuatan standar pendidikan yang seragam. SIM ini bisa diarahkan untuk memfasilitasi 
efektivitas dan efisiensi yang lebih baik lagi dalam pengelolaan sumber daya baik pada level daerah, propinsi, maupun nasional.

\section{PEMANFAATAN TEKNOLOGI INFORMASI UNTUK PENDIDIKAN}

Dengan perkembangan revolusi Teknologi Informasi menyebabkan lembaga pendidikan bukan sebagai satusatunya sumber informasi karena begitu banyaknya sumber-sumber lain yang tersedia bahkan secara cuma-cuma. Dengan perkembangan internet misalnya, sebagai sumber informasi alternatif yang canggih, mengakibatkan informasi yang diperoleh hanya dengan "mengklik" di atas papan ketik komputer, segala informasi yang diinginkan dapat diperoleh dengan cepat. Kemajuan pesat di bidang Teknologi Informasi tentunya akan memberikan perubahan besar terhadap pola pendidikan konvensional. Guru yang awalnya menjadi sumber informasi yang paling dominan akan berubah menjadi mediator dan fasilitator bagi upaya penemuan ilmu pengetahuan peserta didiknya.

Dalam Era Desentralisasi/Otonomi Pendidikan, pola dan bahan interaksi antara peserta didik dan lembaga pendidikan perlu dirumuskan kembali. Terkait dengan market driven era, maka era desentralisasi akan menjadikan peserta didik semakin bebas menentukan pilihannya, yang berkaitan baik dengan potensi lokal, kebutuhan lokal dan masalah lokal.

Secara garis besar dengan dukungan perkembangan teknologi informasi akan terjadi kecenderungan perubahan sebagai berikut:

1. Pendidikan yang hanya berlangsung di dalam kelas digantikan dengan keluwesan dalam hal cara dan media penyampaian. Dalam kaitan itu, peserta didik semakin luwes menentukan mata pelajaran apa yang dipilih sesuai kebutuhannya.

2. Pendidikan bukan lagi sekedar transfer ilmu pengetahuan dan keterampilan tetapi akan diganti dengan kegiatan bersama-sama menemukan ilmu pengetahuan.

3. Pendidikan dengan model face-to face akan jauh semakin berkurang dan digantikan fasilitas akses teknologi informasi, terutama untuk hal-hal yang bersifat pengajaran, simulasi dengan contohcontoh tiga dimensi, yang bisa lebih memberikan pemahaman secara cepat.

4. Peranan face-to-face tidak akan hilang, namun kualitasnya akan dituntut untuk terus meningkat, di samping itu, sifat desentralisasi anak mendorong pentingnya keberadaan kelas tersebar dan guru tersebar sehingga misalnya pendidikan SMA di Jakarta bisa diakses oleh siswa SMA di Papua dengan kelas dan guru-guru yang ada di Papua namun dengan standar kualitas SMA di Jakarta.

Standar fisik dan jumlah peserta didik tanpa kualitas yang memadai tidak akan mendapat tempat secara signifikan dalam era persaingan global. Dalam era revolusi teknologi informasi standar kualitas global harus menjadi perhatian tanpa mengesampingkan kearifan lokal masyarakat. Kalau CIN, ESPN, BBC dan lain-lain dapat kita nikmati dari seluruh pelosok tanah air, sebentar lagi berbagai penyedia jasa pendidikan dari seluruh dunia akan berbuat yang sama. Sebagai perputaran uang, modal dan barang, sebentar lagi ilmu pengetahuan bisa dijajakan ke seluruh pelosok bumi. Di situ, pendidikan nasional harus bersaing dengan kecenderungan global. Apakah pendidikan nasional hanya akan mensuplai lapangan kerja nasional atau 
juga global, itupun dengan catatan lapangan kerja nasional yang seperti apa yang akan disuplai oleh sistem pendidikan nasional kita. Tanpa kesadaran kompetitif global ini, jangan-jangan pendidikan nasional kita hanya akan memenuhi lapisan paling bawah dari struktur tenaga kerja global.

Pemanfaatan teknologi informasi, khususnya internet dikalangan institusi pendidikan pada berbagai jenjang dan jenis nampaknya masih belum merata, kecuali pada perguruan tinggi umumnya telah akses dengan teknologi internet ini. Pada jenjang dan jalur pendidikan lain di mana proses belajarnya relatif masih konvensional (tatap muka), yang sesungguhnya sudah tidak lagi mampu memenuhi kebutuhan pendidikan untuk masyarakat yang semakin kompleks, memerlukan inovasi dan media yang mampu menanggulanginya.

Negara Indonesia yang merupakan negara kepulauan sebetulnya sangat tepat jika terus mengembangkan kemajuan teknologi informasi ini sebagai media utama dalam meningkatkan kualitas sumber daya manusianya. Namun tidak semudah yang dibayangkan, kendalakendala untuk merealisasikan tentunya sangat banyak misalnya:

1. Penggunaan teknologi informasi memerlukan media internet. Ungkapan yang mengatakan bahwa "tidak ada media terbaik" kiranya berlaku juga bagi media internet. Media ini baik kalu digunakan untuk tujuan yang tepat dalam situasi yang tepat juga. Ada beberapa kelemahan yang perlu dikemukakan dalam paper ini. Penggunaan internet memerlukan infrastruktur yang memadai internet dapat dioperasikan kalau ada jaringan listrik dan ada jaringan telepon. Tempat-tempat yang belum mempunyai jaringan listrik dan telepon tidak dapat menggunakan internet.

2. Penggunaan internet mahal. Untuk dapat menggunakan internet orang harus mempunyai komputer yang dilengkapi dengan modem, tenaga listrik, fasilitas telepon dan hubungan dengan internet provider yang dapat diperoleh melalui langganan. Harga komputer dan modemnya mahal tetapi membeli sekali dapat dipakai dalam waktu yang lama. Sedangkan biaya penggunaan saluran telepon, tenaga listrik dan langganan provider internet harus dibayar setiap bulan.

3. Komunikasi melalui internet seringkali lamban. Arus komunikasi melalui internet seringkali berjalan lamban. Lebih-lebih kalau informasi itu mengandung gambar, chart, bagan, gambar bergerak, suara dan sebagainya. Lambatnya arus informasi ini dapat menyebabkan proses belajar menjadi membosankan.

4. Kendati masalah infrastruktur sudah tidak jadi masalah, misalnya sudah ditangani oleh pemerintah otonomi tetapi tidak dapat kita pungkiri bahwa tidak semua guru menguasai penggunaan media teknologi informasi, sehingga transfer kepada anak didiknya akan terganggu.

Untuk memberikan arahan bagi pemerintah dalam menentukan kebijakan di bidang teknologi informasi, Tim Koordinasi Telematika Indonesia telah membuat Kerangka Teknologi Informasi Nasional. Kerangka Teknologi Informasi Nasional memberikan koridor pengembangan teknologi informasi pada berbagai sektor yang dianggap penting, meliputi sektor pemerintahan, bisnis, 
pemberdayaan masyarakat, pendidikan dan demokrasi.

Teknologi informasi harus mengambil peran sentral dalam upaya mengembangkan pendidikan, baik itu proses pembelajaran formal maupun pelatihan. Dalam proses pembelajaran, teknologi informasi dapat berperan lebih dalam proses pembelajaran jarak jauh. Walaupun upaya yang sudah dilaksanakan oleh Universitas Terbuka selama ini cukup memberikan hasil, teknologi informasi diharapkan mampu meningkatkan kualitas pembelajaran serta memperluas jangkauan dan cakupannya, terutama untuk sasaran kelompok masyarakat berbeda. Beberapa kelompok masyarakat yang selama ini belum memperoleh akses ke pendidikan, misalnya peserta didik di SD sampai SLTA, diharapkan dapat memperoleh manfaat dari penerapan teknologi informasi. Peningkatan kualitaspun dapat pula diharapkan melalui pemanfaatan guru dan dosen yang terbaik secara nasional. Proses pembelajaran jarak jauh juga dapat dimanfaatkan untuk proses pelatihan bagi berbagai kelompok masyarakat, misalnya usaha kecil dan menengah, birokrasi pada pemerintah daerah.

Teknologi informasi juga memiliki peran penting, terutama dalam konteks desentralisasi dan otonomi daerah. Sebagai akibat dari pengelolaan tersentralisir selama ini, kapasitas pengelolaan di daerah menjadi terbatas. Teknologi informasi dapat menyediakan sarana pelatihan dan penyebarluasan informasi bagi pelaksana pembangunan di daerah, sehingga secara sistematis dan terprogram kapasitas yang saat ini tersentralisir di pusat dapat ditransfer ke daerah.

Pemanfaatan teknologi informasi dalam proses pendidikan, dengan sasaran yang secara cermat dipilih, bahan ajar yang berkualitas, serta metodologi pengajaran yang tepat akan mampu mendukung proses pemerataan dan meng- urangi kesenjangan antar daerah. Pencapaian tujuan ini akan merupakan dukungan langsung kepada persatuan dan kesatuan bangsa Indonesia.

Strategi untuk mencapai TI untuk pendidikan adalah melalui hal-hal sebagai berikut:

1. Tersedianya akses untuk pembelajaran jarak jauh untuk semua lapisan masyarakat yang membutuhkan pada tahun 2010, yang dicerminkan antara lain dengan angka partisipasi yang meningkat, keragaman mata ajar yang luas spekturmnya, keragaman tingkat kecanggihan pemanfaatan Informasi And Communication Technology (selanjutnya disingkat ICT) serta peningkatan jumlah dan jenis institusi yang terlibat.

2. Pemanfaatan teknologi informasi dalam proses pelatihan di semua sektor, baik pemerintahan (pusat dan daerah), swasta, maupun sektor non-pemerintahan lainnya (2005).

\section{PENUTUP}

Pendidikan harus dilaksanakan dalam kerangka pembentukan seorang manusia atau dalam filsafat Yunani kuno disebut Paideia. Dengan perkembangan revolusi teknologi informasi menyebabkan lembaga pendidikan bukan sebagai satu-satunya sumber informasi karena begitu banyaknya sumber-sumber lain yang tersedia bahkan secara cuma-cuma. Maka peran guru adalah mediator dan fasilitator bagi upaya penemuan ilmu pengetahuan peserta didik yang relevan, tepat guna, bernuansa kemanusiaan dan kasih sayang sehingga melahirkan manusia-manusia beramal shaleh selain berkemampuan tinggi. 


\section{DAFTAR RUJUKAN}

Alan Chute, Melody Thompson and Burton Hancock, 1999, The McGraw-Hill Handbook of Distance Learning.

Alatas, Abubakar (2002) Virtual Campus: a Project Proposal. Jakarta: SEAMOLEC

Anwas, Oos M. (2000), Internet: Peluang dan Tantangan Pendidikan Nasional. Jakarta: Jurnal Teknodik Depdiknas.

Basuni, Dina Farida, Indikator Teknologi Informasi dan Komunikasi Tahun 2001, Pusat Pengkajian dan Penerapan Teknologi Informasi dan Elektronik (P3TIE), BPPT, 2001. Depdiknas, Garis Besar Kebijakan Teknologi Informasi Nasional, 2002)

Hartanto, A.A. dan Purbo, O.W. (2002), Teknologi e-Learning Berbasis $P H P$ dan MySQL, Elex Media Komputindo, Jakarta

Keegan, D. (1990). Foundations of Distance Education. ( $\left.2^{\text {nd }} E d\right)$. London: Routledge

Indeks

informasi, 1, 199, 200, 201, 202, 203, 204, 205, 206, 207

kualitas, 1, 199, 202, 205, 206
Kerangka Teknologi Informasi Nasional untuk Pendidikan, Tim Koordinasi Telematika Indonesia, Februari 2001

Lawanto, Oemardi, (2000). Pembelajaran Berbasis Web sebagai Media Komplemen Kegiatan Pendidikan dan Pelatihan. Makalah Video Conference: Bandung-Surabaya: Depdiknas.

Moore, M.G, \& Kearsley, G. (1996). Distance Education: A Systems View. Belmont, California: Wadsworth Publishing Company.

Soekartawi (2002). Prospek Pembelajaran melalui Internet. Makalah

Suryo, Roy (2001). Information Technology and Communication Technology for Open and Distance Learning. Jakarta: PustekkomSEAMOLEC

Wardhani, IGAK, (2000). Program Tutorial dalam Sistem Pendidikan Tinggi Terbuka dan Jarak Jauh. Jurnal Pendidikan Terbuka dan Jarak Jauh, I (2), hal. 41-52.

pendidikan, 1, 199, 202, 203, 204, 205 , 206, 207

teknologi, 1, 199, 200, 201, 202, 203, 204, 205, 206, 207 